\title{
PENGARUH PUPUK KOMPOS DAN PUPUK ORGANIK CAIR NASA TERHADAP PERTUMBUHAN DAN HASIL TANAMAN MENTIMUN (Cucumis sativus L.) VARIETAS MISANO F1
}

\author{
Emiliana Lidya $^{1}$, Noor Jannah ${ }^{2}$, dan Abdul Rahmi ${ }^{3}$ \\ ${ }^{1}$ Agroteknologi, Fakultas Pertanian, Universitas 17 Agustus 1945 Samarinda, Indonesia. \\ ${ }^{2}$ Dosen Fakultas Pertanian, Universitas 17 Agustus 1945 Samarinda 75124, Indonesia. \\ E-Mail: lidya@untag-smd.ac.id
}

\begin{abstract}
ABSTRAK
Pengaruh Pupuk Kompos dan Pupuk Organik Cair Nasa Terhadap Pertumbuhan dan Hasil Tanaman Mentimun (Cucumis sativus L.) Varietas Misano F1.Tujuan penelitian adalah untuk : (1) mengetahui pengaruh pemberian pupuk kompos dan POC Nasa serta interaksinya terhadap pertumbuhan dan hasil tanaman mentimun varietas Misano F1; dan (2) memperoleh dosis pupuk kompos dan konsentrasi POC Nasa yang sesuai untuk pertumbuhan dan hasil tanamam mentimun, sehingga diperoleh hasil yang tinggi.

Penelitian menggunakan Rancangan Acak Lengkap (RAL) dalam percobaan faktorial 4 x 4 yang diulang sebanyak3 kali. Faktor pertama adalah dosis pupuk kompos (K) yang terdiri atas4 taraf :tanpa pupuk kompos (k0),

48g polibag ${ }^{-1}(\mathrm{k} 1) .64 \mathrm{~g} \mathrm{polibag}^{-1}(\mathrm{k} 2)$; dan $80 \mathrm{~g} \mathrm{polibag}^{-1}(\mathrm{k} 3)$. Faktor kedua adalah konsentrasi POC Nasa (D) terdiri atas 4 taraf :tanpa POC Nasa (d0), $1 \mathrm{ml} \mathrm{l}^{-1}$ air (d1), $2 \mathrm{ml} \mathrm{l}^{-1}$ air (d2), dan $3 \mathrm{ml}^{-1}$ air (d3).

Hasil penelitian menunjukkan bahwa : (1) perlakuan pupuk kompos berpengaruh nyata terhadap berat satu buah dan berat buah per tanaman; berpengaruh sangat nyata terhadap panjang tanaman pada umur 15 dan 30 hari setelah tanam, dan diameter buah, tetapi berpengaruh tidak nyata terhadap jumlah buah per tanaman. Buah yang paling berat dihasilkan pada perlakuan $48 \mathrm{~g}$ polibag $^{-1}(\mathrm{k} 1)$ yaitu $3,77 \mathrm{~kg}$ tanaman ${ }^{-1}$, sedangkan yang paling ringan dihasilkan pada perlakuan $80 \mathrm{~g}$ polibag $^{-1}(\mathrm{k} 3)$ yaitu $3,06 \mathrm{~kg} \operatorname{tanaman}^{-1}$; (2) perlakuan POC Nasa berpengaruh nyata terhadap berat satu buah; dan berpengaruh sangat nyata terhadap panjang tanaman pada umur 30 hari setelah tanam dan diameter buah, tetapi berpengruh tidak nyata terhadap panjang tanaman pada umur 15 hari setelah tanam, jumlah buah dan berat buah per tanaman; dan (3)perlakuan interaksi antara pupuk kompos dan POC Nasa berpengaruh nyata terhadap berat satu buah dan berpengaruh sangat nyata terhadap diameter buah, tetapi berpengaruh tidak nyata terhadap panjang tanaman pada umur 15 dan 30 hari setelah tanam, jumlah buah dan berat buah per tanaman.
\end{abstract}

Kata kunci : kompos, POC Nasa, mentimun.

\begin{abstract}
Effect of Compost Fertilizer and Nasa Liquid Organic Fertilizer on the Growth and Yield of Cucumber (Cucumis sativus L.) Misano F1 Variety. The research objective were to study the effect of compost fertilizer and Nasa liquid organic fertilizer (POC Nasa) and its interaction on the growth and yield of cucumber and also to find the proper dosage of compost fertilizer and POC Nasa concentration for obtaining the best growth and yield of cucumber.

The research used Completely Randomized Design (CRD) in $4 \times 4$ factorial experiment and three replications. The factor was the dosage of compost fertilizer (K) consisting of 4 levels : no compost fertilizer application $\left(\mathrm{k}_{0}\right), 48 \mathrm{~g}$ polybag $^{-1}\left(\mathrm{k}_{1}\right), 64 \mathrm{~g}_{\text {polybag }}{ }^{-1}\left(\mathrm{k}_{2}\right)$; and $80 \mathrm{~g} \mathrm{polybag}^{-1}\left(\mathrm{k}_{3}\right)$. The second factor was the concentration of POC Nasa (D) consisting 4 levels : no POC Nasa application $\left(\mathrm{d}_{0}\right), 1 \mathrm{ml} \mathrm{l}^{-1}$ water $\left(\mathrm{d}_{1}\right), 2 \mathrm{ml} \mathrm{l}^{-}$ ${ }^{1}$ water $\left(\mathrm{d}_{2}\right)$, and $3 \mathrm{ml} \mathrm{l}^{-1}$ water $\left(\mathrm{d}_{3}\right)$.

The results showed that: (1) the compost fertilizer treatment affected significantly on the weight of one fruit and the weight of fruit per plant, it affected very significantly on the plant lenght at age 15 and 30 days after planting, and fruit diameter, but it did not affect significantly on the number of fruit per plant. The best production was produced at $48 \mathrm{~g}$ polybag $^{-1}(\mathrm{k} 1)$ treatment of $3,77 \mathrm{~kg}^{-1 a n t^{-1}}$, while the least one was produced at the $80 \mathrm{~g} \mathrm{polybag}^{-1}(\mathrm{k} 3)$ treatment of $3,06 \mathrm{~kg} \mathrm{plant}^{-1}$; (2) the POC Nasa treatment affected significantly on the weight of one fruit; and it affected very significanly on the plant lenght at age 30 days after planting and
\end{abstract}


fruit diameter, but it did not affect significantly on the plant lenght at age 15 days after planting, number of fruit per plant, and fruit weight per plant; and (3) the interaction treatment between compost fertilizer and POC Nasa affected significantly on the weight of one fruit and affected very significantly on the fruit diameter, but did not affect significantly on the plant lenght at age 15 and 30 after planting, the number of fruit and fruit weight per plant.

Key words : Compost Fertilizer, Nasa Liquid Organic Fertilizer, Cucumber.

\section{PENDAHULUAN}

Mentimun (cucumber sativus L.) merupakan tanaman semusim yang sudah dikenal masyarakat luas, sayuran mentimun dapat diolah menjadi berbagai macam bentuk makanan seperti acar, asinan, pencampur gado-gado, lalap, penghias hidangan dan lain sebagainya.

Di Kabupaten Kutai Barat, pengembangan tanaman mentimun memiliki peluang usaha yang cukup menjanjikan karena produksi yang ada belum mencukupi kebutuhan masyarakat, petani yang mengusahakan masih sedikit serta harga jual yang cukup tinggi. Untuk mencukupi kebutuhan mentimun tersebut sebagian besar disuplai dari luar daerah terutama dari Kota Samarinda.

Secara umum produksi tanaman mentimun di daerah Kutai Barat masih tergolong rendah yang disebabkan oleh beberapa faktor diantaranya adalah : benih yang digunakan bukan merupakan benih unggul, teknik budidaya belum intensif, dan tingkat kesuburan tanahnya yang tergolong rendah. Untuk memperbaiki dan meningkatkan pertumbuhan dan hasil tanaman mentimun dapat dilakukan dengan berbagai usaha seperti perluasan areal tanam (ekstensifikasi), rehabilitasi lahan sertausaha peningkatan produksi tanaman per satuan luas lahan (intensifikasi) yang dapat dilakukan salah satu diantaranya adalah dengan pemberian pupuk.

Salah satu jenis pupuk yang sangat dianjurkan dalam usaha tani adalah pupuk organik. Pemberian pupuk organik dapat memperbaiki yaitu : granulasi tanah, aerasi dan drainase tanah, meningkatkan kemampuan tanah menahan air, memperbaiki sifat kimia dan sifat biologis tanah, dan tidak menyebabkan polusi tanah dan air (Musnamar, 2003).Penggunaan pupuk kompos tidak hanya menambah unsur hara tetapi juga dapat menjaga fungsi tanah sehingga tanaman dapat tumbuh dengan baik (https://id.wikipedia.org/wiki/pupuk_orga nik, 2017).

Di samping pemberian pupuk organik kompos, untuk meningkatkan produksi tanaman mentimun dapat juga dilakukan dengan memberikan pupuk organik cair (POC) Nasa. POC Nasa diproduksi oleh PT Natural Nusantara dan dirancang secara khusus terutama untuk mencukupi kebutuhan nutrisi lengkap pada tanaman juga untuk peternakan dan perikanan yang dibuat murni dari bahan-bahan organik (https://www.youtube.com/watch? $v=Y i M$ KM_UMLgc15 Apr 2016).

Tujuan penelitian adalah : (1) untuk mengetahui pengaruh pemberian pupuk kompos dan POC Nasa serta interaksinya terhadap pertumbuhan dan hasil tanaman mentimun varietas Misano F1; dan (2) untuk memperoleh dosis pupuk kompos dan konsentrasi POC Nasa yang sesuai untuk pertumbuhan dan hasil tanamam mentimun, sehingga diperoleh hasil yang tinggi.

\section{METODA PENELITIAN}

\subsection{Tempat dan Waktu}

Penelitian dilaksanakan di Kelurahan Barong Tongkok, Kecamatan Barong Tongkok, Kabupaten Kutai Barat, 
Provinsi Kalimantan Timur. Pada bulan Februari-April 2017.

\subsection{Bahan dan Alat}

Bahan yang digunakan adalah benih tanaman mentimun varietas Misano F1, media tanam berupa tanah lapisan atas, pupuk kompos, POC Nasa, dan Furadan 3G. Peralatan yang digunakan adalah cangkul untuk mengolah dan menggemburkan tanah, polibag ukuran $30 \times 30 \mathrm{~cm}$, gembor, label, meteran, jangka sorong, timbangan analitik, papan triplek, mangkok, alat tulis, dan kamera.

\subsection{Rancangan Penelitian}

Penelitian menggunakan Rancangan Acak Lengkap (RAL) dalam percobaan faktorial $4 \times 4$, dengan dua faktor perlakuan, dan diulang sebanyak3 kali. Faktor pertama adalah dosis pupuk kompos (K) yang terdiri atas4 taraf :tanpa pupuk kompos (k0), 48g polibag $^{-1}(\mathrm{k} 2), 64 \mathrm{~g}$ polibag $^{-1}$ ( 2 2), dan $80 \mathrm{~g}$ polibag ${ }^{1}(\mathrm{k} 3)$.Faktor kedua adalah konsentrasi POC Nasa (D) terdiri atas 4 taraf: tanpa POC Nasa (d0), $1 \mathrm{ml} \mathrm{l}^{-1}$ air (d1), $2 \mathrm{ml} \mathrm{l}^{-1}$ air (d2), dan $3 \mathrm{ml} \mathrm{l}^{-1}$ air (d3).

\subsection{Prosedur Penelitian}

Kegiatan penelitian yang dilakukan yaitu antara lain : (1) penyiapan media tanam, (2) pemberian pupuk kompos, (3) persiapan benih, (4) penanaman, (5) penyemprotan pupuk POC Nasa, (6) pemeliharaan tanaman meliputi : penyiraman, penjarangan, penyiangan gulma, pemasangan ajir, pemberian Furadan 3G, dan pemanenan.

\subsection{Analisis Data}

Data yang dikumpulkan dalam penelitian ini adalah sebagai berikut : (1) data utama : panjang tanaman (cm) pada umur 15 dan 30 hari setelah tanam, kumlah buah per tanaman, diameter buah, berat satu buah, dan berat buah per tanaman; dan (2) data penunjang yaitu hasil analisis sifat kimia tanah dari Laboratorium Tanah Fakultas Pertanian Universitas Mulawarman Samarinda.

Analisis data dilakukan dengan menggunakan sidik ragam, gila hasil sidik ragam berpengaruh nyata $(\mathrm{F}$ hitung $>\mathrm{F}$ tabel $5 \%$ ) atau berpengaruh sangat nyata ( $\mathrm{F}$ hitung $>$ $\mathrm{F}$ tabel $1 \%$ ), maka untuk membandingkan dua rata-rata perlakuan dilakukan uji lanjutan dengan uji beda nyata terkecil (BNT) taraf nyata $5 \%$.

\section{HASIL PENELITIAN DAN PEMBAHASAN}

Hasil penelitian pengaruh pupuk kompos dan POC Nasa serta interaksinya terhadap rata-rata panjang tanaman mentimun pada umur 15 dan 30 hari setelah tanam, jumlah buah per tanaman, diameter buah, berat saatu buah dan berat buah per tanaman disajikan pada Tabel 1 . 
Tabel 1. Rekapitulasi Hasil Penelitian Pengaruh Pupuk Kompos dan POC Nasa serta Interaksinya terhadap Pertumbuhan dan Hasil Tanaman Mentimun Varietas Misano F1

\begin{tabular}{|c|c|c|c|c|c|c|}
\hline \multirow{2}{*}{$\begin{array}{l}\text { Faktor-Faktor } \\
\text { Perlakuan }\end{array}$} & \multicolumn{2}{|c|}{ Panjang Tanaman $(\mathrm{cm})$} & \multirow{2}{*}{$\begin{array}{l}\text { Jumlah Buah per } \\
\text { Tanaman (buah) }\end{array}$} & \multirow{2}{*}{$\begin{array}{l}\text { Diameter Buah } \\
(\mathrm{cm})\end{array}$} & \multirow{2}{*}{$\begin{array}{c}\text { Berat Satu } \\
\text { Buah } \\
(\mathrm{kg})\end{array}$} & \multirow{2}{*}{$\begin{array}{c}\text { Berat Buah } \\
\left(\mathrm{kg} \mathrm{tanaman}^{-1}\right)\end{array}$} \\
\hline & $15 \mathrm{HST}$ & $30 \mathrm{HST}$ & & & & \\
\hline $\begin{array}{l}\text { Perlakuan Pupuk } \\
\text { Kompos (K) }\end{array}$ & $* *$ & $* *$ & tn & $* *$ & $*$ & $*$ \\
\hline Tanpa Kompos (k0) & $101,67 \mathrm{~b}$ & $129,67 \mathrm{c}$ & 6,50 & $4,85 \mathrm{~d}$ & $0,56 \mathrm{ab}$ & $3,65 a b$ \\
\hline $48 \mathrm{~g}$ polibag $^{-1}(\mathrm{k} 1)$ & $97,92 \mathrm{~b}$ & $146,42 b$ & 6,92 & $5,43 \mathrm{c}$ & $0,61 \mathrm{a}$ & $3,77 \mathrm{a}$ \\
\hline $64 \mathrm{~g}$ polibag $^{-1}(\mathrm{k} 2)$ & $116,42 \mathrm{a}$ & $167,08 \mathrm{a}$ & 6,25 & $6,13 \mathrm{~b}$ & $0,52 \mathrm{~b}$ & $3,08 \mathrm{~b}$ \\
\hline Tanpa POC Nasa (D) & 105,83 & $148,00 \mathrm{~b}$ & 7,00 & $5,67 \mathrm{~d}$ & $0,54 \mathrm{~b}$ & 3,37 \\
\hline $1 \mathrm{ml} \mathrm{l}^{-1}$ air $(\mathrm{d} 1)$ & 100,50 & $146,67 \mathrm{~b}$ & 6,92 & $5,88 \mathrm{c}$ & $0,52 \mathrm{~b}$ & 3,49 \\
\hline $2 \mathrm{ml} \mathrm{l}^{-1}$ air (d2) & 94,25 & $158,08 \mathrm{a}$ & 6,25 & $6,06 \mathrm{~b}$ & $0,61 \mathrm{a}$ & 3,57 \\
\hline $3 \mathrm{ml} \mathrm{l}^{-1}$ air (d3) & 105,42 & $164,50 \mathrm{a}$ & 5,75 & $6,33 \mathrm{a}$ & $0,54 \mathrm{~b}$ & 3,12 \\
\hline $\mathrm{k} 0 \mathrm{~d} 3$ & 106,67 & 147,00 & 6,50 & $5,04 \mathrm{jk}$ & $0,57 \mathrm{~b}$ & 3,67 \\
\hline k1d0 & 105,00 & 133,33 & 7,67 & $5,23 \mathrm{ij}$ & $0,60 \mathrm{~b}$ & 3,17 \\
\hline $\mathrm{k} 1 \mathrm{~d} 1$ & 88,33 & 135,00 & 8,33 & $5,33 \mathrm{i}$ & $0,50 \mathrm{~b}$ & 3,67 \\
\hline $\mathrm{k} 1 \mathrm{~d} 2$ & 85,00 & 152,00 & 5,33 & $5,58 \mathrm{gh}$ & $0,80 \mathrm{a}$ & 4,33 \\
\hline $\mathrm{k} 1 \mathrm{~d} 3$ & 113,33 & 165,33 & 7,33 & $5,57 \mathrm{~h}$ & $0,53 \mathrm{~b}$ & 3,90 \\
\hline $\mathrm{k} 2 \mathrm{~d} 0$ & 126,67 & 168,33 & 7,33 & $5,81 \mathrm{fg}$ & $0,55 \mathrm{~b}$ & 3,83 \\
\hline $\mathrm{k} 2 \mathrm{~d} 1$ & 113,67 & 158,33 & 6,67 & $5,81 \mathrm{fg}$ & $0,51 \mathrm{~b}$ & 3,40 \\
\hline $\mathrm{k} 2 \mathrm{~d} 2$ & 110,33 & 175,00 & 5,33 & $6,13 \mathrm{e}$ & $0,51 \mathrm{~b}$ & 2,73 \\
\hline $\mathrm{k} 2 \mathrm{~d} 3$ & 115,00 & 166,67 & 4,33 & $6,77 \mathrm{~d}$ & $0,54 \mathrm{~b}$ & 2,33 \\
\hline $\mathrm{k} 3 \mathrm{~d} 0$ & 85,00 & 171,00 & 6,33 & $7,01 \mathrm{c}$ & $0,51 \mathrm{~b}$ & 3,10 \\
\hline $\mathrm{k} 3 \mathrm{~d} 1$ & 90,00 & 173,33 & 6,33 & $7,46 \mathrm{~b}$ & $0,50 \mathrm{~b}$ & 3,17 \\
\hline
\end{tabular}

Keterangan : angka rata-rata yang diikuti dengan huruf yang sama adalah berbeda tidak nyata menurut hasil uji lanjut dengan BNT taraf $5 \%$; th = berpengaruh tidak nyata; $*$ =berpengaruh nyata; $* *$ = berpengaruh sangat nyata; dan HST = hari setelah tanam,

Pengaruh pupuk kompos berdasarkan hasil sidik ragam menunjukkan bahwa perlakuan kompos berpengaruh sangat nyata terhadap pertumbuhan panjang tanaman mentimun pada umur 15 dan 30 hari setelah tanam. Hasil penelitian yang disajikan pada Tabel 1 menunjukkan bahwa panjang tanaman pada umur 15 hari setelah tanaman pada perlakuan kompos $48 \mathrm{~g}_{\text {polibag }^{-1}}(\mathrm{k} 1)$ dan $80 \mathrm{~g}$ polibag $^{-1}(\mathrm{k} 3)$ memberikan pengaruh yang berbeda tidak nyata dibandingkan dengan tanpa kompos ( $\mathrm{k} 0)$, dan hanya perlakuan $64 \mathrm{~g}$ polibag $^{-1}$ (k2) yang berbeda nyata. Kemudian pada pengamatan panjang tanaman umur 30 hari setelah tanam menunjukkan bahwa perlakuan $64 \mathrm{~g}$ polibag $^{-1}$ (k2) dan $80 \mathrm{~g} \mathrm{polibag}^{-1}(\mathrm{k} 3)$ berbeda nyata dibandingkan dengan perlakuan tanpa kompos (k0), sedangkan perlakuan $48 \mathrm{~g}_{\text {polibag }^{-1}}(\mathrm{k} 1)$ berbeda tidak nyata. Panjang tanaman pada umur 30 hari setelah tanaman dengan semakin bertambahnya dosis pemberian pupuk kompos menghasilkan tanaman yang makin panjang. Hal ini disebabkan karena pemberian pupuk kompos dapat meningkatkan ketersediaan unsur hara terutama unsur hara $\mathrm{N}$ yang sangat dibutuhkan untuk memacu pertumbuhan vegetatif tanaman. Seperti dinyatakan oleh Munawar (2011) bahwa unsur N merupakan penyusun asam amino, protein dan asam nukleat serta klorofil; Unsur $\mathrm{N}$ yang berperan penting dalam pertumbuhan vegetatif tanaman.

Pada parameter jumlah buah per tanaman, perlakuan pupuk kompos berpengaruh tidak nyata. Hasil penelitian yang disajikan pada Tabel 1 
menunjukkan bahwa jumlah buah per tanaman yang dihasilkan perlakuan $48 \mathrm{~g}$ polibag $^{-1}(\mathrm{k} 1), 64$ g polibag $^{-1}(\mathrm{k} 2)$, dan 80 g polibag $^{-1}(\mathrm{k} 3)$ berturut-turut 6,$92 ; 6,25$; dan 6,33 buah tanaman ${ }^{-1}$, sedangkan pada perlakuan tanpa pupuk kompos (k0) yaitu 6,50 buah tanaman ${ }^{-1}$. Hal ini disebabkan karena setiap tanaman mempunyai kapasitas/kemampuan tertentu dalam menghasilkan jumlah buah tergantung pada faktor dalam tanaman itu sendiri dan juga oleh faktor lingkungan. Seperti dinyatakan Darjanto dan Satifah (2002) bahwa pada umumnya banyaknya buah masak yang dapat dipungut pada waktu panen ditentukan oleh faktor dalam (seperti jumlah bunga yang dihasilkan, persentase bunga yang mengalami penyerbukan, persentase bunga yang mengalami pembuahan, persentase buah muda yang dapat tumbuh terus hingga menjadi buah masak); dan faktor lingkungan (seperti keadaan tanah yang terlalu basah atau kering, kesuburan tanah).

Pada parameter diameter buah, perlakuan pupuk kompos berpengaruh sangat nyata. Hasil penelitian yang disajikan pada Tabel 1 menunjukkan bahwa perlakuan $48 \mathrm{~g}_{\text {polibag }}{ }^{-1}(\mathrm{k} 1), 64 \mathrm{~g}$ polibag $^{-1}(\mathrm{k} 2)$, dan $80 \mathrm{~g} \mathrm{polibag}^{-1}(\mathrm{k} 3)$ menghasilkan diameter buah yang lebih besar dibandingkan perlakuan tanpa pupuk kompos (k0) yaitu berturut-turut $5,43 \mathrm{~cm} ; 6,13 \mathrm{~cm}$; dan $7,53 \mathrm{~cm}$, sedangkan pada perlakuan tanpa pupuk kompos (k0) hanya sebesar 4,85 cm. Selanjutnya pada parameter berat satu buah, perlakuan pupuk kompos berpengaruh nyata. Hasil penelitian menunjukkan bahwa perlakuan $48 \mathrm{~g}$ polibag $^{-1}$ (k1) menghasilkan berat satu buah yang paling besar yaitu $0,61 \mathrm{~kg}$, diikuti perlakuan tanpa kompos $(\mathrm{k} 0)$ yaitu $0,56 \mathrm{~kg}$, sedangkan berat satu buah yang paling kecil dihasilkan pada perlakuan 64 g polibag $^{-1}$ (k2) dan 80 g polibag $^{-1}(\mathrm{k} 3)$ yaitu $0,52 \mathrm{~kg}$. Hal ini menunjukkan bahwa meskipun pemberian kompos dapat meningkatkan ukuran diameter buah, namun tidak selalu menghasilkan berat satu buah yang lebih berat, karena juga akan ditentukan oleh komponen buah lainnya seperti panjang buah dan kepadatan buah.

Hasil penelitian menunjukkan bahwa perlakuan pupuk kompos berpengaruh nyata terhadap berat buah per tanaman. Hasil penelitian pada Tabel 1 menunjukkan bahwa perlakuan $48 \mathrm{~g}$ polibag $^{-1}(\mathrm{k} 1)$ menghasilkan berat buah per tanaman yang paling tinggi yaitu 3,77 $\mathrm{kg}$, diikuti perlakuan tanpa kompos $(\mathrm{k} 0)$ yaitu $3,65 \mathrm{~kg}$ dan perlakuan $64 \mathrm{~g}$ polibag $^{-}$ 1 (k2) yaitu 3,08 kg, sedangkan berat buah yang paling rendah dihasilkan pada perlakuan $80 \mathrm{~g}$ polibag $^{-1}(\mathrm{k} 3)$ yaitu 3,06 $\mathrm{kg}$. Tingginya hasil buah yang dicapai pada perlakuan $48 \mathrm{~g}$ polibag $^{-1}$ (k1) didukung oleh parameter banyak jumlah buah per tanaman dan ukuran berat satu buah yang lebih baik dibandingkan dengan perlakuan pemberian pupuk kompos lainnya. Hal ini disebabkan dengan pemberian pupuk organik yaitu berupa kompos, maka unsur hara makro dan unsur hara mikro yang dibutuhkan oleh tanaman dapat terpenuhi, selain itu juga adanya perbaikan sifat fisik tanah dan sifat biologis tanah, sehingga tanaman dapat tumbuh dengan baik dan memberikan hasil buah yang tinggi. Sesuai dengan pendapat Lingga dan Marsono (2003) pemberian pupuk organik selain memperbaiki kesuburan tanah, juga dapat memperbaiki sifat fisik dan biologis tanah. Dengan adanya perbaikan sifat-sifat tanah tersebut, maka tanaman dapat tumbuh dengan baik dan dapat menghasilkan produksi buah yang tinggi.

Hasil penelitian menunjukkan bahwa pemberian pupuk kompos dengan dosis $64 \mathrm{~g}_{\text {polibag }}{ }^{-1}(\mathrm{k} 2)$ dan $80 \mathrm{~g}$ polibag $^{-1}(\mathrm{k} 3)$ menghasilkan jumlah buah per tanaman yang lebih sedikit, berat satu 
buah yang lebih ringan dan berat buah per tanaman yang lebih rendah dibandingkan dengan perlakuan $48 \mathrm{~g}$ polibag $^{-1}(\mathrm{k} 1)$. Keadaan ini disebabkan karena kandungan bahan organik awal yaitu 5,40\% (tergolong sangat tinggi) dan $\mathrm{N}$ total tanah awal sebesar $0,69 \%$ (tergolong tinggi) sehingga dengan penambahan bahan organik dari pupuk kompos diduga dapat meningkatkan ketersediaan unsur $\mathrm{N}$ dalam tanah yang dapat memacu pertumbuhan vegetatif tanaman yang lebih dominan dibandingkan dengan pertumbuhan bagian generatif. Seperti dinyatakan oleh Winarso (2005), kelebihan unsur hara $\mathrm{N}$ akan meningkatkan petumbuhan vegetatif tanaman, tetapi akan menurunkan kuantitas dan kualitas produksi tanaman.

Pengaruh POC Nasa berdasarkan Hasil sidik ragam menunjukkan bahwa perlakuan POC berpengaruh tidak nyata terhadap pertumbuhan panjang tanaman mentimun pada umur 15 hari setelah tanam. Hal ini disebabkan karena perlakuan pemberian POC Nasa dilakukan pertama kali pada umur 14 hari setelah tanam, sehingga pengaruhnya belum terlihat nyata pada pengamatan panjang tanaman umur 15 hari setelah tanam. Namun pada pengamatan panjang tanaman pada umur 30 hari setelah tanam menunjukkan bahwa pemberian POC Nasa berpengaruh sangat nyata. Hasil penelitian pada Tabel 1 menunjukkan bahwa pemberian POC Nasa dengan konsentrasi $2 \mathrm{ml} \mathrm{l}^{-1}$ air (d2) dan $3 \mathrm{ml} \mathrm{l}^{-1}$ air (d3) menghasilkan pertumbuhan panjang tanaman yang lebih panjang dibandingkan perlakuan tanpa POC Nasa (d0) dan $1 \mathrm{ml} \mathrm{l}^{-1}$ air (d1). Hal ini disebabkan karena pemberian POC Nasa dapat meningkatkan ketersediaan sejumlah unsur hara khususnya unsur hara $\mathrm{N}$ yang sangat dibutuhkan untuk pertumbuhan vegetatif tanaman. Seperti dinyatakan oleh Prihmantoro (2006) bahwa unsur $\mathrm{N}$ diperlukan tanaman untuk merangsang pertumbuhan vegetatif tanaman terutama batang, cabang dan daun.

Pada parameter jumlah buah per tanaman, perlakuan POC Nasa berpengaruh tidak nyata. Hasil penelitian yang disajikan pada Tabel 1 menunjukkan bahwa jumlah buah per tanaman yang dihasilkan perlakuan $1 \mathrm{ml}$ $\mathrm{l}^{-1}$ air (d1), $2 \mathrm{ml} \mathrm{l}^{-1}$ air (d2), dan $3 \mathrm{ml} \mathrm{l}^{-1}$ air (d3) berturut-turut 6,$92 ; 6,25$; dan 5,75 buah tanaman ${ }^{-1}$, sedangkan pada perlakuan tanpa POC Nasa (d0) yaitu 7,00 buah tanaman ${ }^{-1}$. Hal ini disebabkan karena masing-masing tanaman memiliki kemampuan tertentu dalam membentuk jumlah buah yang sangat dipengaruhi oleh faktor dalam tanaman dan juga oleh faktor lingkungan. Seperti dinyatakan Darjanto dan Satifah (2002) bahwa pada umumnya banyaknya buah masak yang dapat dipungut pada waktu panen ditentukan oleh faktor dalam dan faktor lingkungan.

Pada parameter diameter buah, perlakuan POC Nasa berpengaruh sangat nyata. Hasil penelitian pada Tabel 1 menunjukkan bahwa pemberian POC Nasa dengan konsentrasi $1 \mathrm{ml} \mathrm{l}^{-1}$ air (d1), $2 \mathrm{ml} \mathrm{l}^{-1}$ air (d2), dan $3 \mathrm{ml} \mathrm{l}^{-1}$ air (d3) menghasilkan ukuran diameter buah masing-masing yaitu $5,88 \mathrm{~cm}, 6,06 \mathrm{~cm}$, dan $6,33 \mathrm{~cm}$, ukuran diameter buah tersebut adalah lebih besar dibandingkan dengan perlakuan tanpa POC Nasa (d0) yaitu 5,67 cm; Selanjutnya pada parameter berat satu buah, perlakuan POC Nasa berpengaruh nyata. Hasil penelitian pada Tabel 1 menunjukkan bahwa pemberian POC Nasa dengan konsentrasi $1 \mathrm{ml} \mathrm{l}^{-1}$ air (d1), $2 \mathrm{ml} \mathrm{l}^{-1}$ air (d2), dan $3 \mathrm{ml} \mathrm{l}^{-1}$ air (d3) menghasilkan berat satu buah yaitu berturut-turut 0,52 $\mathrm{kg}, 0,61 \mathrm{~kg}$, dan $0,54 \mathrm{~kg}$, sedang pada perlakuan tanpa POC Nasa (d0) yaitu ,54 kg. Secara umum dapat dinyatakan bahwa pemberian POC Nasa dapat meningkatkan ketersediaan unsur hara 
untuk tanaman mentimun, sehingga akan berpengaruh terhadap pembentukan buah. Hal ini disebabkan dengan pemberian POC Nasa dapat meningkatkan serapan unsur hara oleh tanaman, sehingga tanaman dapat tumbuh dengan baik dan memberikan hasil yang baik. Seperti dinyatakan bahwa POC Nasa memiliki fungsi multiguna, salah satu diantaranya adalah dapat meningkatkan kuantitas dan kualitas produksi tanaman serta kelestarian

lingkungan/tanah(https://www.youtube.co m/watch? $=$ YiMKM_UMLgc15 Apr 2016).

Hasil sidik ragam menunjukkan bahwa perlakuan POC Nasa berpengaruh tidak nyata terhadap berat buah per tanaman. Hasil penelitian menunjukkan bahwa perlakuan $1 \mathrm{ml} \mathrm{l}^{-1}$ air (d1) dan $2 \mathrm{ml}$ $\mathrm{l}^{-1}$ air (d2) menghasilkan berat buah per tanaman yaitu berturut-turut $3,49 \mathrm{~kg}$ dan $3,57 \mathrm{~kg}$, hasil tersebut adalah lebih tinggi dibandingkan dengan perlakuan tanpa POC Nasa (d0) yaitu 3,37 kg, sedangkan yang paling rendah dihasilkan pada perlakuan $3 \mathrm{ml} \mathrm{l}^{-1}$ air (d3) yaitu 3,12 kg. Hal ini menunjukkan bahwa pemberian pupuk daun seperti POC Nasa sampai dengan konsentrasi tertentu dapat memperbaiki hasil buah tanaman, namun bila konsentrasi pupuk daun tersebut ditingkatkan lagi dapat menurunkan hasil buah tanaman. Seperti dinyatakan oleh Lingga dan Marsono (2003) bahwa dalam hal pemberian pupuk daun adalah beberapa hal yang mutlak harus diperhatikan salah satu diantaranya adalah konsentrasi yang dibuat/diberikan harus sesuai dengan petunjuk, jangan sampai berlebihan karena akan berpengaruh buruk terhadap tanaman.

Pengaruh interaksi pupuk kompos dan pupuk POC Nasa berdasarkan hasil sidik ragam menunjukkan bahwa interaksi antara faktor pupuk kompos dan faktor POC Nasa berpengaruh nyata sampai berpangaruh sangat nyata terhadap diameter buah dan berat satu buah, tetapi berpengaruh tidak nyata terhadap panjang tanaman pada umur 15 dan 30 hari setelah tanam, jumlah buah dan berat buah per tanaman. Keadaan tersebut menunjukkan bahwa antara faktor pupuk kompos dan faktor POC Nasa dapat saling bersama-sama dan atau tidak secara bersama-sama atau sendirisendiri dalam mempengaruhi pertumbuhan dan hasil tanaman mentimun. Seperti dijelaskan oleh Gomez dan Gomez (1995) bahwa dua faktor perlakuan dikatakan berinteraksi apabila pengaruh suatu faktor perlakuan berubah pada saat perubahan taraf faktor perlakuan lainnya. Selanjutnya dinyatakan oleh Steel dan Torrie (1991) bahwa bila pengaruh interaksi berbeda tidak nyata, maka disimpulkan bahwa diantara faktor-faktor perlakuan tersebut bertindak bebas satu terhadap lainnya. Kejadian ini disebabkan karena selama pertumbuhan dan perkembangan tanaman mentimun terdapat fase-fase pertumbuhan yang berbeda-beda intensitasnya, sehingga kebutuhan unsur hara selama proses tersebut juga berbedabeda atau tidak sama banyaknya.

Hasil penelitian yang disajikan pada Tabel 1 (rekapitulasi) menunjukkan bahwa pemberian kompos 48 g polibag $^{-1}$ dan pemberian POC Nasa dengan konsentrasi $2 \mathrm{ml} \mathrm{l}^{-1}$ air cenderung menghasilkan hasil buah yang lebih baik. Keadaan ini disebabkan karena pemberian kedua pupuk tersebut dapat meningkatkan ketersediaan dan serapan unsur hara oleh tanaman mentimun, sehingga tanaman dapat tumbuh baik dan memberikan hasil yang lebih baik. Seperti dikemukakan oleh Dwidjoseputro (1998) bahwa tanaman akan tumbuh subur apabila unsur hara yang dibutuhkannya tersedia dalam jumlah yang cukup dan seimbang. 


\section{KESIMPULAN}

Berdasarkan hasil penelitian dan pembahasan dapat diambil kesimpulan yaitu sebagai berikut : perlakuan pupuk kompos berpengaruh nyata terhadap berat satu buah dan berat buah per tanaman; berpengaruh sangat nyata terhadap panjang tanaman pada umur 15 dan 30 hari setelah tanam, dan diameter buah, tetapi berpengaruh tidak nyata terhadap jumlah buah per tanaman. Buah yang paling berat dihasilkan pada perlakuan 48 g polibag $^{-1}$ (k1) yaitu 3,77 kg tanaman ${ }^{-1}$, sedangkan yang paling ringan dihasilkan pada perlakuan $80 \mathrm{~g}^{\text {polibag }}{ }^{-1}(\mathrm{k} 3)$ yaitu $3,06 \mathrm{~kg}$ tanaman $^{-1}$. Perlakuan POC Nasa berpengaruh nyata terhadap berat satu buah; dan berpengaruh sangat nyata terhadap panjang tanaman pada umur 30 hari setelah tanam dan diameter buah, tetapi berpengruh tidak nyata terhadap panjang tanaman pada umur 15 hari setelah tanam, jumlah buah dan berat buah per tanaman. Perlakuan interaksi antara pupuk kompos dan POC Nasa berpengaruh nyata terhadap berat satu buah dan berpengaruh sangat nyata terhadap diameter buah, tetapi berpengaruh tidak nyata terhadap panjang tanaman pada umur 15 dan 30 hari setelah tanam, jumlah buah dan berat buah per tanaman.

\section{DAFTAR PUSTAKA}

Darjanto dan S. Satifah. 2002. Biologi Bunga dan Teknik Penyerbukan Silang Buatan. Penebar Swadaya, Jakarta.

Dwidjoseputro, D. 1998. Pengantar Fisiologi Tumbuhan. Gramedia, Jakarta.
Gomez, K.A dan A.A. Gomez. 1995. Prosedur Statistik untuk Penelitian Pertanian (Terjemahan A. Sjamsuddin dan J.S Baharsyah). Edisi Kedua. UI Press, Jakarta.

Lingga, P. dan Marsono. 2003. Petunjuk Penggunaan Pupuk. Penebar Swadaya, Jakarta.

Munawar, A. 2011. Kesuburan Tanah dan Nutrisi Tanaman. IPB Press, Bogor.

Musnamar, E.I. 2003. Pembuatan dan Aplikasi Pupuk Organik Padat. Penebar Swadaya, Jakarta.

Prihmantoro, H. 2006. Memupuk Tanaman Sayuran. Penebar Swadaya, Jakarta.

Steel, R.G.D dan J. H. Torrie. 1991. Prinsip dan Prosedur Statistika Suatu Pendekatan Biometrik. Gramedia Pustaka Utama, Jakarta.

Winarso, S. 2005. Kesuburan Tanah dan Dasar Kesehatan dan Kualitas Tanah. Gava Media, Yogyakarta.

https://id.wikipedia.org/wiki/Pupuk_orga nikKompos merupakan sisa bahan organik yang berasal dari tanaman, hewan, dan limbah organik yang telah mengalami proses ... ...(diunduh Jumat, 27 Januari 2017)

Https://www.youtube.com/watch? $V=y i m k$ m_umlgc15 Apr 2016 ... Manfaat Pupuk Oganik Produk Nasa (diunduhtanggal 6 Januari 2017) 